\section{Forthcoming Events}

[Meetings marked with an asterisk are open to the public.] Sunday, December 2

British Museum (Natural History), at 3 and 4.30.Dr. K. G. Blair : "Sexual Dimorphism in Insects".*

\section{Monday, December 3}

British Museum (Natural History), at 11.30.-.Dr. Malcolm Smith : "Poisonous Snakes and their Venom".*

London School of Hygiene and Tropical Medicine, at 5.-Dr. L. W. Hackett : "Malaria in Europe" (Heath Clark Lectures. Succeeding lectures on December 4, $5,6$ and 7$)$.* $^{*}$

Royal Geographical Society, at 5.30.-Mr. Hugh Ruttledge's film of the Mount Everest Expedition, 1933, and other Mount Everest films.

\section{Tuesday, December 4}

Royal Society of ARts, at 4.30.-E. W. Bovill : "Empire Production of Essential Oils for Perfumery".

\section{Wednesday, December 5}

University College, London, at 5.-Miss Violet Mason: "Folklore of the Cotswolds".*

\section{Friday, December 7}

International Society of Leather Trades' Chemists, at 10 a.m.- (at University College, Gower Street, W.C.1).-A symposium on "Technical Aspects of Emulsions".*

Society of Chemical Industry (Liverpool Section), at 6 - (at the University).--DD. J. T. Conroy : "The Alkali and Associated Industries-a Retrospect" (Hurter Memorial Lecture).*

Bedson Club (Armstrong College, Newcastre upon Tyne), at 6.30.-Dr. W. H. Mills: "Some Stereochemical Questions" (Bedson Lecture).

Institute of Chemistry (London and South Eastern Counties Section).--Streatfield Memorial Lecture.

Royal Institumion, at 9.-Dr. C. H. Desch: "The Crystallisation of Alloys".

British Institute of Radiology, December 5-7. Annual Congress and exhibition of X-ray apparatus to be held at the Central Hall, Westminster, S.W.I. To be opened by Sir Humphry Rolleston.

December 6.-Dr. H. H. Berg: "The Digestive Mucosa" (Silvanus Thompson Memorial Lecture).

December 7.-Sir William Bragg: "X-Rays and the Coarse Structure of Materials" (Mackenzie Davidson Memorial Lecture).

\section{Official Publications Received}

\section{GREAT BRITAIN AND IRELAND}

University of Reading: The National Institute for Research in Dairying. Annual Report for the Year ending 31st July 1933. Pp. 93. (Shinfleld : National Institute for Research in Dairying.)

Survey of Thunderstorms in the British Islands. Summer Thunderstorms : Third Annual Report, 1933. By S. Morris Bower and others. Pp. $36+v i+6$ plates. (Huddersfleld : Thunderstorm Census Organisation.) $2 s .6 d$.

University of Birmingham : Executive Board of Mining Research. Report on the Work of the Mining Research Laboratory during the Year 1933. Pp. 20. (Birmingham.)

Ministry of Labour. Reports of Investigations into the Industrial Conditions in certain Depressed Areas of 1, West Cumberland and Haltwhistle; 2, Durham and Tyneside; 3, South Wales and Monmouthshire ; 4, Scotland. (Cmd. 4728.) Pp. 240. (London: H.M. Stationery Office.) $38.6 \dot{d}$. net.

"This Surprising Lancashire!" Some Views and Notes published at the direction of the Municipal Finance Committee on behalf of the Lancashire Industrial Development Council. Pp. 48. (Manchester : Lancashire Industrial Development Council; London: W. H. Smith and Son, Ltd.) $6 d$.

Rubber and Agriculture. Pp. 64. (London: Rubber Growers' Association.) Free.

\title{
OTHER COUNTRIES
}

Report of the Aeronautical Research·Institute, Tôkyô Imperial University. No. 111: A Simple Method of Calculating the Induced Velocity of a Monoplane Wing. By Itirô Tani. Pp. 65-76. 15 sen.
No. 112: Motion of Stretched String in a Turbulent Flow of Air. No. 112: Motion of Stretched String in a Turbulent Flow of Air.
By Daizo Nukiyama. Pp. $77-100.20$ sen. (Tôkyô : Koseikai Publishing Office.)

Science Reports of the Tokyo Bunrika Daigaku, Section B. No. 25: Brachyura from the Coast of Kyusyu, Japan. By Tune Sakai. Pp. 281-330+ plates 17-18. 80 sen. No. 26 : Bryozoa Fauna in the Vicinity of the Shimoda Marine Biological Station. By Yaichiró Okada. Pp. $20+2$ plates. 30 sen. No. 27 : The Aquatic Insects at Nikkô. By Yaichirô Okada and Isamu Horasawa. Pp. 21-27. 15 sen. (Tokyo: Maruzen Co., Ltd.

Journal of the Faculty of Agriculture, Hokkaido Imperial University. Vol. 33, Part 5: Spiders from Hokkaido. By Saiburo Saito. Pp. 267-362 + plates 12-15. (Tokyo: Maruzen Co., Ltd.)

Travaux du Laboratoire de Microbiologie de la Faculté de Pharmacie de Nancy. 1934, Fascicule 7. Pp. 234. (Nancy: Faculté de Pharmacie.

Forest Bulletin No. 85: A Record of the Results obtained with Experimental Treated Sleepers laid in the Indian Railways between 1911 and 1916. By S. Kamesam. Pp. îi +35 . (Delhi: Manager of Publications.) 8 annas ; $10 d$.

Report of the Botanical Survey of India for 1932-33. Pp. 12. (Calcutta: Royal Botanic Gardens.)

Bulletin of the Madras Government Museum. New Series, General Section, Vol. 3, Part 1: The Three Main Styles of Temple Architecture recognised by the Silpa-Sanstras. By Dr. F. H. Gravely and T. N. recognised by the Silpa-Sāstras. By 1)r. F. H. Gravely and T. N.
Ramachandran. Pp. $26+2$ plates. (Madras: Government Press.)

Memoirs of the Geological Survey of India. Vol. 63, Part 2: The Iron-Ore Deposits of Bihar and Orissa. By H. Cecil Jones. Pp. iv + Iron-Ore Deposits of Bihar and Orissa. By H. Cecil Jones. Pp. iv +
$167-302+x x v+$ plates $13-32$. (Calcutta : Geological Survey of India.) 7.10 rupees ; 138 .

Journal of the Indian Institute of Science. Vol. 17A, Part 7 : Preparation of Sugar Syrup from Cashew Apple (Anacardium occidentale, Linn.). By M. Srinivasan. Pp. 85-94. 14 annas. Vol. 17B, Part 2 Studies in Dielectrics, Part 1: The Effect of Superimposed Magnetic Fields on the Breakdown Voltage of Dielectrics; Part 2: The Effect of Superimposed Magnetic Fields on the Permittivity and Power Factor of Dielectrics. By N. V. Narayanaswami and F. N. Mowdawalla. Pp. 19-46. 2.4 rupees. Vol. 17B, Part 3: Radio Field Intensity Measurements at Bangalore during the Polar Year. By P. L. Narayanan. Pp. 47-67. 1.8 rupees. Vol. 17B, Part 4: Studies in Dielectrics, Part 3: The Effect of Successive Discharges on the Dielectric Strength of Liquids; Part 4: The Effect of Impurities on the Breakdown Voltage of Transformer Oil. By B. S. Ramaswamy,
N. V. Narayanaswami and F. N. Mowdawalla. Pp. 69-90. 1.12 N. V. Narayanaswami and F. N. Mowdawalla. Pp. 69-90. 1.12
rupees. Vol. 17B, Part 5: Brush Contact Drop in D.C. Machines. rupees. Vol. 17B, Part 5: Brush Contact Drop in D.C. Machines.
By M. V. Kesavo Rao. Pp. 91-100. 1 rupee. (Bangalore: Indian Institute of Science.)

Hints to Prospectors and Owners of Treatment Plants. Sixth edition. Pp. 64. (Perth: Government Printer.) $9 d$.

National Research Council. Transactions of the American Geophysical Union, Fifteenth Annual Meeting, April 26, 27, 28, 1934, Pp. 258. Part 2. Pp. 259-634. (Washington, D.C. : National A cademy of Sciences.)

Proceedings of the California Academy of Sciences, Fourth Series. Vol. 21, No. 15: The Templeton Crocker Expedition to Western Polynesian and Melanesian Islands, 1933-Notes on the Reptiles and Amphibians, with the Description of a New Species of Sea-Snake. By Joseph R. Slevin. Pp. 183-188. Vol. 21, No. 16: The Templeton 1933--Notes on the Birds. By M. E. McLellan Davidson. Pp. 189-198. (San Francisco)

Obras completas y Correspondencia cientifica de Florentino Ameghino. Vol. 13: Formaciones sedimentarias de Patagonia. Edición Oficial ordenada por el Gobierno de la Provincia de Buenos Aires. Dirigida por Alfredo J. Torcelli. Pp. $999+7$ plates. (La Plata.)

Province of Alberta : Geological Survey Division. Research Council of Alberta, Report No. 30: Geology of Central Alberta. By John A. Allan and Ralph L. Rutherford. Pp. iii $+41+v+3$ plates. (Edmonton: University of Alberta.) 1 dollar.

University of Alberta.) 1 dollar. Sudan Government. Annual Report of the Gezira Agricultural
Research Service for the Year ended 31st December 1933, relating to Experimental Results obtained in the Season 1932-33. Pp. xiii + 183 . Experimental Results obtained in the Season 1932-33.

Weports of the Newfoundland Fishery Research Commission. Vol. Reports of the Newfoundland Fishery Research Commission. Vol.
2, No. 2: Annual Report, Year 1933. Pp. 117+12 plates. (St. John's : Newfoundland Fishery Research Commission.) 1 dollar.

Meddelelser om Grønland udgivne af Kommissionen for VidensMeddelelser om Grønland udgivne af Kommissionen for Videns-
kabelige. Undersøgelser i Grønland, Bd. 79, Nr. 10: The Godthaab kabelige. Undion 1928 - Copepoda. By P. Jespersen. Pp. 166. (København : C. A. Reitzels Forlag.) $8.00 \mathrm{kr}$.

C. A. Reitzels Forlag.) $8.00 \mathrm{kr}$. Publication of the Netherlands Geodetic Commission (Uitgegeven door de Rijkscommissie voor Graadmeting en Waterpassing.) Gravity Expeditions at Sea, 1923-1932. Vol. 2: Report of the Gravity Expedition in the Atlantic of 1932 and the Interpretation of the Results. By F. A. Vening Meinesz, with the collaboration of Prof. J. H. F.
Umbgrove and $\mathrm{Ph}$. $\mathrm{H}$. Kuenen. Pp. iii $+208+5$ plates. Tables belongUmbgrove and $\mathrm{Ph}$. H. Kuenen. Pp. iii $+208+5$ plates. Tables belong
ing to Gravity Expeditions at Sea, 1923-1932. By F. A. Vening ing to Gravity Expeditions at Sea, 1923-1932. By F. A. Vening

Meinesz. Isostatic Reductions, Elevations a
Zones. Pp. 61. (Delft: J. Waltman, Jr.)

Editorial and Publishing Offices :

MACMILLAN \& CO., LTD.

ST. MARTIN'S STREET, LONDON, W.C.2

Telephone Number: WHITEHALL 883 I Telegraphic Address : PHUSIS, LESQUARE, LONDON 